\title{
Shariah Governance Structure of Islamic Financial Institutions in Sri Lanka
}

\author{
Hayathu Mohamed Ahamed Hilmy,
} South Eastern University of Sri Lanka

Rusni Hassan,

\author{
International Islamic University Malaysia
}

\begin{abstract}
Shariah governance plays a key role in ensuring integrity of Islamic financial system. The structure and the process of Shariah governance has been proposed by the international standard setting bodies for Islamic Financial Institutions (IFIs) to follow and incorporate Shariah governance practices in their operations and financial products. This study aims to investigate the Shariah governance practice in Sri Lanka that practices dual financial system (conventional and Islamic finance) for the past twenty years, with a special focus on process and structure. The qualitative method is employed in this study whereby the primary data are gathered in the form of interview while secondary data are collected through research articles, annual reports, official websites, magazines and newspaper. This study found there are gaps and shortcomings in the Shariah governance practice at IFIs in Sri Lanka particularly in the structure and the process as compare to the international framework and guidelines issued by international standard setting body such as AAOIFI and IFSB. The main contribution of this study is to put forward recommendations to rectify the gaps and to further enhance the Shariah governance practices in Sri Lankan IFIs.
\end{abstract}

Keywords: Shariah Governance; Shariah Review; Shariah Audit; Sri Lankan Islamic Financial Institutions 


\section{Introduction}

Islamic finance is a system that strictly complies with Islamic law without involvement of Shariah prohibited elements, which is otherwise the key element in conventional banking. Design to promote and economic justice (Mizushima, 2013), Islamic finance is a way to accommodate the values of Islam in finance in accordance with Islamic law (Shariah). Shariah governance framework is a mechanism used by Islamic Financial Institutions (IFIs) to ensure Shariah compliance and also to mitigate Shariah noncompliance risk, which is costly and also adversely affect reputation of and business continuity of IFIs (Haqqi, 2014). Shariah governance is an integral part of the IFIs by which the institutions validate their conformity with Islamic teachings in all operational activities of the IFIs including management, administration, operation, products, and services. The well-structured Shariah governance process is vital to maintain Shariah compliance in the organisational practices of IFIs.

The Shariah governance framework is an effective tool for ensuring and measuring competency and efficiency of Shariah compliance of Islamic financial operation. The history of Sri Lanka in Islamic finance can be traced back in 1997 when Amana Investments was created by founder Osman Kassim (Amana Bank, 2019). To date, most of the big players in conventional finance in the country have started Islamic windows (Patel, 2017). However, there has been a lack of empirical research on Shariah governance in Sri Lanka. The scandal of Ceylinco Profit Sharing and Investment Corporation is a shock for the Islamic financial industry as well as for the public. The depositors believe that the board of director are responsible for the premature collapse due to the misuse of powers through mismanagement, misappropriation, fraudulent dealings, violation of Shariah rules and other statuary requirements (Daily FT, 2015). It is therefore important to examine Shariah governance practices of Sri Lankan IFIs, especially given the growth of Islamic finance industry in Sri Lanka is growing, among countries like Bangladesh and Singapore (Kuwait Finance House Research Ltd, 2013 p. 29).

International standard setting bodies such as Accounting Auditing Organization for Islamic Financial Institutions (AAOIFI) and Islamic Financial Services Board (IFSB) have proposed for governance standards on Shariah (AAOFI, 2015; IFSB, 2009). IFIs, in turn, should follow those guidelines to ensure Shariah compliance of the institutions as well as to cater the expectation of the stakeholders particularly the investors and the public. This study intends to explore Shariah governance practices in IFIs in Sri Lanka and the extent of compliance with the Shariah standard they follow. Further, this study identifies the gap between the Standard or guidelines and the current practices of those institutions. This study systematically analyses the gap and issues faced by the IFIs with an attempt to propose the rectification plans and to provide the best ways to ensure healthy practices in terms of structure and process of Shariah governance in those institutions.

\section{Shariah Governance}

Shariah is the backbone and basis for viability of IFIs, scholars in Islamic finance declared that Shariah governance is the most essential and unique portion of the

International Journal of Management and Applied Research, 2019, Vol. 6, No. 4 
Islamic financial system which is lacking in conventional financial institutions, it aims to legitimatise financial products in line with Shariah principles and it advises on every step of each contract, and increases the disclosure and transparency in order to improve oversight of the IFIs which would lead to strengthen investors' confidence in the industry (Haqqi, 2014; Hasan, 2011; Mizushima, 2013). Like corporate governance, Shariah governance is about accountability, integrity, responsibility, and transparency prohibit IFIs from engaging in fraudulent activities (Buallay, 2019). Shariah governance has been defined "as the overall system that manages the conformity of the activities of Islamic banks and financial institutions to the precepts of Shariah pertaining to transactions" (Ginena and Hamid, 2015, p.80).

The term 'Shariah governance' consists of two words, 'Shariah' and 'governance'. Shariah can be translated simply as Islamic Law or Islamic rulings or way of life. However, Shariah has very detailed meanings in Islam. The literal definition of the term Shariah is 'the road to the watering place' or 'the straight path to be followed' and technically it is defined as 'the laws that God revealed to Prophet Muhammad (pbuh) in the Qur'an and Sunnah'(Muhammad, 1414). Shariah refers to divine laws that are obligatory upon mankind in order to achieve success in this world and the hereafter.

Governance means 'the action or manner of governing a state, organisation and the like' (Oxford Dictionaries, 2013). The word 'governance' implies an act of steering, guiding, or direcing someone or an organisation. Hasan (2010) defined 'governance' as "the style or way an organisation, institution, or corporation is guided, steered and controlled". Consequently, the definition of Shariah governance should be reflected in terms of Shariah as well as governance. Hence, the IFSB-10 defined Shariah governance in the context of the IFIs as:

"A set of institutional and organizational arrangements through which Islamic financial institutions ensure that there is an effective independent oversight of Shariah compliance over the issuance of relevant Shariah pronouncements, dissemination of information and an internal Shariah compliance review" (IFSB, 2009, p.2).

The definition provided by the IFSB-10 implies that there are three main features of Shariah governance system and key functions that are accountable for ensuring Shariah governance in the respective IFIs has been illustrated by the IFSB-10 as follows:

Table 1: Shariah governance system in IFIs

\begin{tabular}{lll}
\hline & $\begin{array}{l}\text { Key Functions in Typical } \\
\text { Financial Institutions }\end{array}$ & Key Functions Exclusive to IFIs \\
\hline Governance & Board of Directors & Shariah Supervisory Board (SSB) \\
Control & Internal/ External auditor & Internal/External Shariah review \\
Compliance & $\begin{array}{l}\text { Regulatory and financial } \\
\text { compliance officers, unit or } \\
\text { department }\end{array}$ & Internal Shariah compliance unit \\
& \multicolumn{2}{c}{ Adapted from: Mizushima (2013, p. 74) }
\end{tabular}

Adapted from: Mizushima (2013, p. 74)

International Journal of Management and Applied Research, 2019, Vol. 6, No. 4 
The above table clearly reflects the structure and the process of Shariah governance of IFIs such as Shariah Supervisory Board (SSB), internal and external audit and review process. In 2011, Bank Negara Malaysia published Shariah Governance Framework, outlining responsibilities and roles of key departments. These lines of responsibilities also serve as lines of defence against Shariah non-compliance risks (Hakim, 2017).

\subsection{Structure of Shariah Governance}

Shariah governance structure can be traced from the governance standards issued by two international standard setting bodies, the AAOIFI and the IFSB. Those standards imply how Shariah governance shall be structured in IFIs. Seven governance standards have been issued by the AAOIFI, namely: Governance Standard for IFIs No. 1: Shariah Supervisory Board Appointment, Composition and Report; Governance Standard for IFIs No. 2: Shariah Review; Governance Standard for IFIs No. 3: Internal Shariah Review; Governance Standard for IFIs No. 4: Audit and Governance Committee; Governance Standard for IFIs No. 5: Independence of Shariah Board which is meant as SSB; Governance Standard for IFIs No. 6: Statement on Governance Principles for Islamic Financial Institutions; and Governance Standard for IFIs No. 7: Corporate Social Responsibility (CSR) (AAOIFI, 2015).

On the other hand, the IFSB issued the IFSB-10 Standard in 2009 that begins with a clear definition of Shariah governance as well as instructions to use the standards. IFSB-10 has explained the Shariah governance standard in five guiding principles which are Part I: General approach of Shariah governance, Part II: Competence, Part III: Independence, Part IV: Confidentiality, and Part V: consistency.

\subsection{Internal and External Structure of Shariah Governance}

The internal arrangements of Shariah governance include a robust internal Shariah control system, internal Shariah audit function, board of directors, and related committees such as the governance committee, senior management, legal, compliance, and internal audit functions (Ginena and Hamid, 2015).

As the management of IFIs is responsible for the extent of Shariah compliance, it is incumbent upon them to have a proper mechanism of internal Shariah review. The Governance Standard No. 3:3 of AAOIFI requires IFIs to carry out internal Shariah review / Shariah audit in order to submit their report to the SSB. 'The internal Shariah review is the integral part of the organs of governance' (AAOIFI, 2015, p.910). Further, Governance Standard No. 4:4 explains the process of internal control and internal audit where by these standards necessitate the proper internal arrangement to carry out internal Shariah compliant function.

Governance Standard 3:5 of AAOIFI emphasizes the internal Shariah review can be carried out by either an internal control department or a part of the internal audit division. If a separate unit or department were established for internal Shariah review, it shall have equal authority of internal audit/internal control department (AAOIFI, 2015). Thus, the AAOIFI is flexible on the establishment of a separate department/unit for internal Shariah review or the duty can be executed by an internal audit department, that is, the AAOIFI Governance Standards do not specify the requirement of establishing a separate internal Shariah audit department.

International Journal of Management and Applied Research, 2019, Vol. 6, No. 4 
The IFSB-10 stated clearly that there should be an Internal Shariah Review Unit (ISRU) and an Internal Shariah Compliance Unit (ISCU) with assigned duties and responsibilities at IFIs. For instance, Standard No. 3(b) states that

"such a task (dissemination of information of such Shariah pronouncements) would normally be undertaken by a designated "internal Shariah compliance unit/department" (ISCU)' (IFSB, 2009, p2) .

and standard No. 3(c) states that "an internal Shariah compliance review/audit for verifying that Shariah compliance has been satisfied, during which any incident of non-compliance will be recorded and reported, and as far as possible, addressed and rectified" (IFSB, 2009, p3).

The above standards affirmed that there should be internal and external departments to ensure that Shariah compliance process is in place.

The external structural arrangements of Shariah governance is referred to Shariah supervisory board, external audit firms, Shariah audit and advisory firms which assist to ensure the Shariah compliance of IFIs from outside (Ginena and Hamid, 2015). Both AAOIFI and IFSB Standards insist on instructional arrangement of Shariah governance by having external and internal structures. The Governance Standard No. 1:3 of AAOIFI has stated that "every Islamic financial Institution shall have a Shariah Supervisory board..." (AAOIFI, 2015, p. 885). To the similar extent, Principle 1.1:10 of IFSB-10 requires for the formation and establishment SSB to provide effective ad adequate services (IFSB, 2009).

Furthermore, AAOIFI and IFSB have issued detailed guiding principles on the external structures of Shariah review and Shariah audit. These procedures have been included in AAOIFI Governance Standards No3.18 and No 24 and IFSB-10 (3(d)). The SSB has to play a vital role in these external arrangements.

\subsection{Shariah Review}

There are two layers of Shariah review conducted by the IFIs. First is the Shariah review handled by the SSB to examine the extent of Shariah compliance of IFIs' products, activities, and business transactions, and second, the Shariah review conducted by an independent internal Shariah audit or as part of the internal audit exercise for the IFIs. The second Shariah review is normally focus on the examination of the extent of Shariah compliance based on the Shariah rulings, guidelines, and instructions issued by the SSB (Hassan, 2011). AAOIFI termed these as Shariah review and internal Shariah review respectively.

Emphasising on the importance of Shariah review and internal Shariah review as the major functions within Shariah governance, AAOIFI Governance Standards No. 2 and 3 and the IFSB in different places explained in detail how Shariah review and internal Shariah review should be conducted, along with providing the reporting manuals. Shariah review has been defined in Governance Standard No. 2.3 of AAOIFI as:

International Journal of Management and Applied Research, 2019, Vol. 6, No. 4 
"An examination of the extent of an IFI's compliance, in all its activities, with the Shariah. This examination includes contracts, agreements, policies, products, transactions, memorandum and articles of association, financial statements, reports and circulars, etc" (AAOIFI, 2015, p.899).

Governance Standard No. 2.4 and 2.5 of AAOIFI explained the objectives and the responsibility of Shariah review. Accordingly, the primary function of Shariah review is to examine the Shariah compliance and to ensure that the operations of IFIs do not violate any standard or guideline issued by the SSB. The overall responsibility of compliance is upon the management of IFIs while the SSB shall assist the management by providing assistance and training. However, the SSB is responsible for forming and expressing opinions on the matters relating to Shariah compliance (AAOIFI, 2015). Other, details of the Shariah review procedures, which involve planning, designing, executing, preparing, and reviewing are discussed in Governance Standard No. 2.7-13. The Shariah review report should be submitted to the AGM.

Internal Shariah review is a complementary process of the Shariah review. Governance Standard No. 3 of AAOIFI explains the process of internal Shariah review. It is an integral part of governance organs of IFIs. The management of IFIs should prepare standards and guidance on the internal Shariah review (AAOIFI, 2015). As the management of IFIs is responsible for the compliance and Shariah compliance aspects of the IFIs, it is mandatory upon them to have a proper mechanism of internal Shariah review. According to AAOIFI Governance Standards, internal Shariah review can be carried out by either an internal control department or as part of the internal audit division.

Governance Standard No. 3.7 of AAOIFI provides guidelines about performing the internal Shariah review such as planning each internal Shariah review and assignment, examining and evaluating internal Shariah review information, reporting, and following up. With regard to reporting, internal Shariah review report shall be prepared at least quarterly (AAOIFI, 2015).

On the other hand, IFSB-10 No.3 defined the internal Shariah review as follows;

"An internal Shariah compliance review/audit for verifying that Shariah compliance has been satisfied, during which any incident of non-compliance will be recorded and reported, and as far as possible, addressed and rectified ..." (IFSB, 2009,p.3).

Further, the IFSB requires IFIs to have an Internal Shariah compliance unit (ISCU) and an Internal Shariah review/audit unit (ISRU) to carry out internal Shariah governance activities. In this context, IFSB has used the term Shariah audit and internal Shariah review to refer to the same meaning or substance.

On the other hand, the guidelines issued by Bank Negara Malaysia (BNM) use the term Shariah audit instead of internal Shariah review. According to Guidelines on Shariah Governance Framework published by BNM, principle 7 covers Shariah review and audit functions. In particular, guidelines 7.7 defined the Shariah audit as follows:

International Journal of Management and Applied Research, 2019, Vol. 6, No. 4 
Shariah audit refers to the periodical assessment conducted from time to time, to provide an independent assessment and objective assurance designed to add value and improve the degree of compliance in relation to the IFI's business operations, with the main objective of ensuring a sound and effective internal control system for Shariah compliance (Bank Negara Malaysia, 2010, p. 23).

It is observed that although the AAOIFI uses the term 'Internal Shariah Review' as opposed to Shariah audit, its guidelines are largely consistent with those of the BNM. As such, the prevailing practices of the industry seem to differentiate the two exercises. Whilst the Shariah review is conducted to enable the SSB to express an opinion that the operations of IFIs are conducted in accordance with the fatwas, rulings, and guidelines issued by the SSB of the IFIs, AAOIFI, national accounting standards and practices (if any), and relevant legislations and regulations applied in the country in which the IFI operates (Shafii et al., 2010). Shariah audit is the final checking on Shariah compliance conducted at the IFIs level. The objective of this exercise is to examine business activities and evaluate the degree of their compliance with fatwas and guidelines issued by the IFI's SSB. It also assesses the efficiency and effectiveness of the existing Shariah control system (Ginena and Hamid, 2015). In short, Shariah review is a regular assessment whereas Shariah audit is a periodic assessment with a wider scope than Shariah review.

\section{Methodology}

The study uses a qualitative approach whereby the random sampling method was applied. Islamic finance providers in Sri Lanka can be categorized into six categories, namely full-fledged Islamic banks, Islamic windows in conventional banks, takaful (insurance) companies, Islamic leasing companies, and Islamic investment companies. Although all of these are IFIs, the products and services offered by each category are different and also there is a possibility that they may be regulated by different laws and regulations that may lead them to practice different governance structures. Hence the researcher will choose one institution from each category to represent the total population of 16 institutions. The primary data were collected through semi structured interviews.

Interviewees of this survey can be classified into two groups. The first groups of respondents are professionals from each of the six categories mentioned above. They have at least three years of experience in Shariah governance either in a Shariah compliance unit, Shariah department, Shariah risk management unit, or other units which are relevant to Shariah governance practice of IFIs. These respondents are individuals from the institutions. The second group of respondents are from the management level of the institutions. These people are from SSBs who are experts in the field and understand Shariah governance and its application. The total numbers of SSB members are 10 in all six IFIs due to multiple sitting of the most members.

The secondary data were gathered by annual reports, official websites, leaflets of IFIs and other relevant materials such as research articles, news, magazines and online information.

International Journal of Management and Applied Research, 2019, Vol. 6, No. 4 


\section{Analysis and Findings}

As the objective of this study is to examine the process and the structure of Shariah governance as practiced by the Sri Lankan IFIs, the researchers analyse the process and structure of Shariah governance as to whether the IFIs comply with the internal and external arrangements guided by the standards that they follow respectively. The methodology employed is by examining the literatures and annual reports to find the gap in the practices and supported with the interview with the officers in the IFIs. Firstly, the standards followed by the IFIs were identified by the respondents during the interview and from their annual reports and leaflets. It was found that, all IFIs follow the AAOIFI Standards, except one IFI that follows both AAOIFI's and IFSB's Standards.

The AAOIFI and the IFSB have directed how the process of Shariah governance should be performed and who shall be responsible for certain functions. As discussed in the literature review, Shariah review and internal Shariah review or Shariah audit are the main functions of Shariah governance. This duty shall be carried out by independent divisions or units assigned by the institutions either internal or external. The perspective of the AAOIFI and the IFSB on the functions of Shariah governance and the delegated divisions for a particular duty are summarised as follows:

Table 2: Summary of Shariah Governance Structure

\begin{tabular}{|c|c|c|}
\hline Functions & AAOIFI & IFSB \\
\hline $\begin{array}{l}\text { Internal } \\
\text { Shariah audit }\end{array}$ & $\begin{array}{l}\text { - Separate internal Shariah } \\
\text { review department } \\
\text { Or } \\
\text { - Internal audit department } \\
\text { - Internal control department }\end{array}$ & $\begin{array}{l}\text { - Internal Shariah compliance } \\
\text { department } \\
\text { - Internal Shariah review/audit } \\
\text { department }\end{array}$ \\
\hline Sha & - Shariah supervisory board & $\begin{array}{l}\text { - Shariah supervisory board } \\
\text { Or } \\
\text { - External Shariah reviewer/ } \\
\text { auditor / firm }\end{array}$ \\
\hline
\end{tabular}

Compiled by Author based on AAOIFI (2015) and IFSB-10

The above table affirms that Shariah review and Internal Shariah audit are crucial functions of Shariah governance and the IFIs shall have internal and external arrangements to handle these duties independently. In this regard, all of the respondents were asked during the interview about the process of Shariah review, internal Shariah review, and the assigned departments to perform such duties.

All of the respondents were aware of both Shariah review and Shariah audit functions; they also confirmed that their institutions have arrangements for such functions. However, different approaches were observed among the IFIs with regard to the structure and the reporting line of Shariah review and Shariah audit process.

The respondents from IFI-A claimed that they have followed IFSB Standards specifically regarding Shariah governance structure and function. This has been supported by the company's annual report, which states that IFI-A has considered the guidelines of IFSB-10 on Shariah governance to structure Shariah Governance

International Journal of Management and Applied Research, 2019, Vol. 6, No. 4 
Framework. Further, IFI-A has a SSB known as the Shariah Supervisory Council (SSC), which is an external independent body. Apart from the SSC, the management committee has a division called Shariah Risk Management Committee. Other than this, there is an internal Shariah supervision department that carries out the Shariah compliance functions, namely Shariah audit, online Shariah compliance process, Shariah inspection, Shariah compliance, Shariah advisory and training and research. The annual report of IFI-A for 2018 explains in a diagram the structure and functions of Shariah governance. Figure 1 illustrates the Shariah governance framework of IFI-A including structure, departments and functions:

Figure 1: Shariah Governance of IFI-A

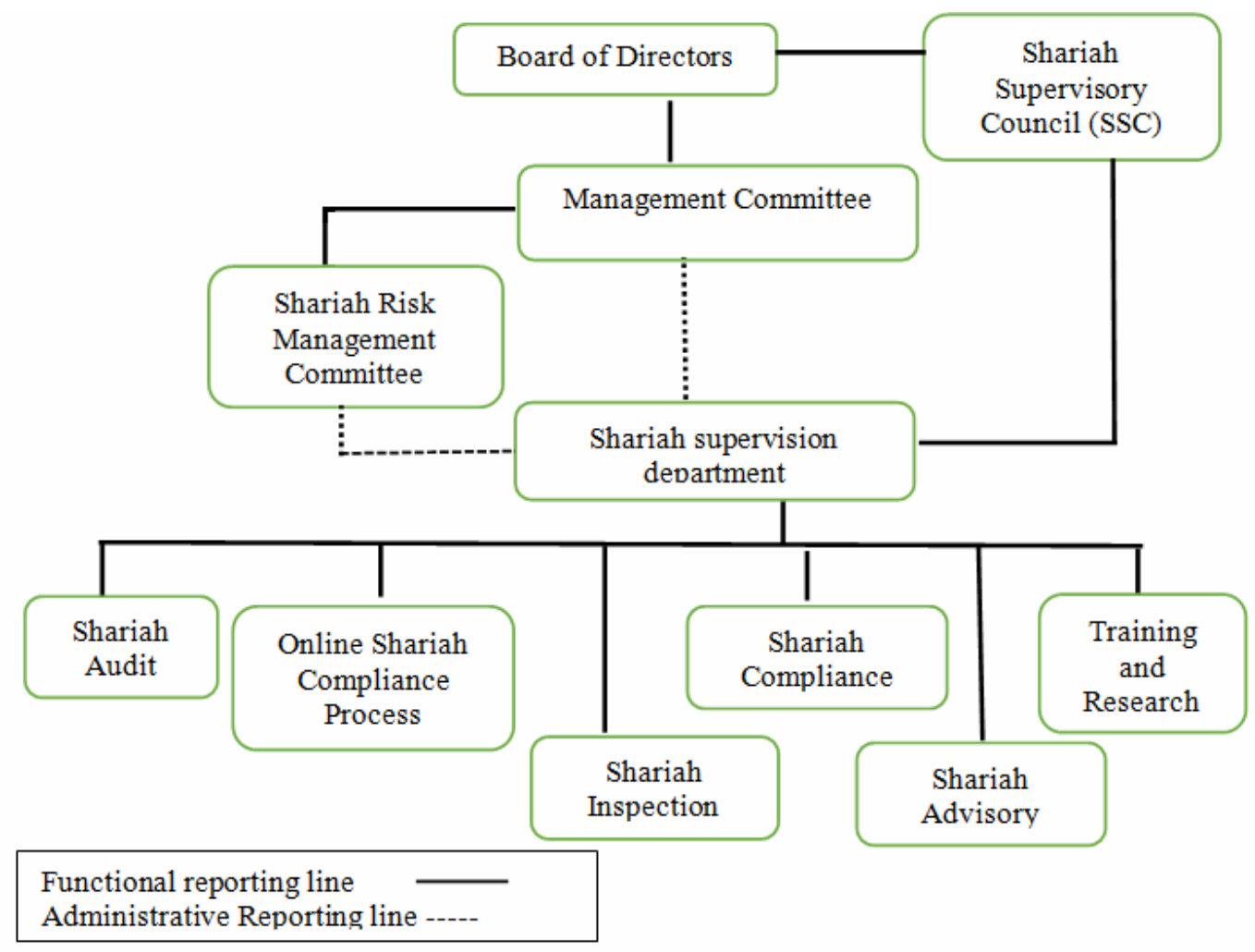

The above diagram illustrates that the IFI-A has an external body and an internal body to perform its Shariah governance functions as guided by IFSB-10. Therefore, in terms of process structure of Shariah governance there is no gap identified between the IFSB-10 and IFI-A.

On the other hand, it has been observed that there are different structures and process among the other IFIs with regard to following AAOIFI Standards on Shariah governance. The IFIs do perform Shariah review and internal Shariah review exercises but approaches to perform these functions seem to be different from one to the other.

The respondent from IFI-B claimed that it has established a SSB known as Shariah Advisory Council (SAC) as an independent external body to supervise and review the entire operation and transactions along with an internal Shariah department that assists

International Journal of Management and Applied Research, 2019, Vol. 6, No. 4 
the SAC by conducting internal Shariah review and audit. The internal Shariah department plays a coordinating role between the SAC and management. He further stated that the internal Shariah review report shall be submitted to the SAC and the SAC performs Shariah review and report to the management.

In general, the structure and process of Shariah governance in IFI-B comply with the prescribed AAOIFI Standards since IFI-B has the external SAC that carries Shariah review function and an internal Shariah department that carries internal Shariah review and audit function. However, the annual report of IFI-B did not provide any information regarding Shariah governance framework to support the claims of the respondents.

On the other hand, the response from IFI-C, D and E claimed that they have same structure and process of Shariah governance whereby Shariah review in the respective IFIs is conducted by an external independent Shariah supervisory board while internal Shariah review and audit are conducted by an in-house Shariah advisor. However, the internal Shariah review is undertaken by a single person rather than a department or unit.

On the contrary, the respondent from IFI-F stated that the company does not have an in-house Shariah advisor but its SSB is vigilant on the institution's products and services and performs Shariah review from time to time. However, the institution shall recruit a Shariah advisor in the immediate future. He justified that currently the internal compliance officer known as internal chief auditor is responsible for Shariah compliance and reports to the SSB and at the same time, he is also involved in the audit process.

According to AAOIFI Governance Standard 3.5 (also refer to Table 5), Shariah review shall be undertaken by either an internal control department or part of the internal audit division or a separate internal Shariah department, but not by a single Shariah advisor. If the duty is being performed by a single person, issue of efficiency may arise as opposed to having a team to perform the work. Therefore, this can be considered as a minor gap of the process structure.

In the case of IFI-F, there is additional issue or gap whereby the qualification of the person conducting Shariah audit may be in question. The Shariah audit and internal Shariah review functions in the IFI-F is under the purview of the chief accountant that do not have required Shariah qualification. However, the respondents justified that the issue of lack of Shariah experts who understand Islamic finance and the nature of current business environment, and therefore, constrained them to employ the internal compliance and audit unit to support the internal Shariah review exercise or function.

It is important to note that all of the IFIs that claimed to follow only the AAOIFI Standards did not publish their Shariah governance structure in their annual reports including IFI-B though it has a governance structure different from others. Hence, based on the collected information, the Shariah governance framework of IFIs in Sri Lanka (except for IFI-A) is illustrated in Figure 2:

International Journal of Management and Applied Research, 2019, Vol. 6, No. 4 
Figure 2: Shariah Governance of Sri Lankan IFIs (except IFI-A)

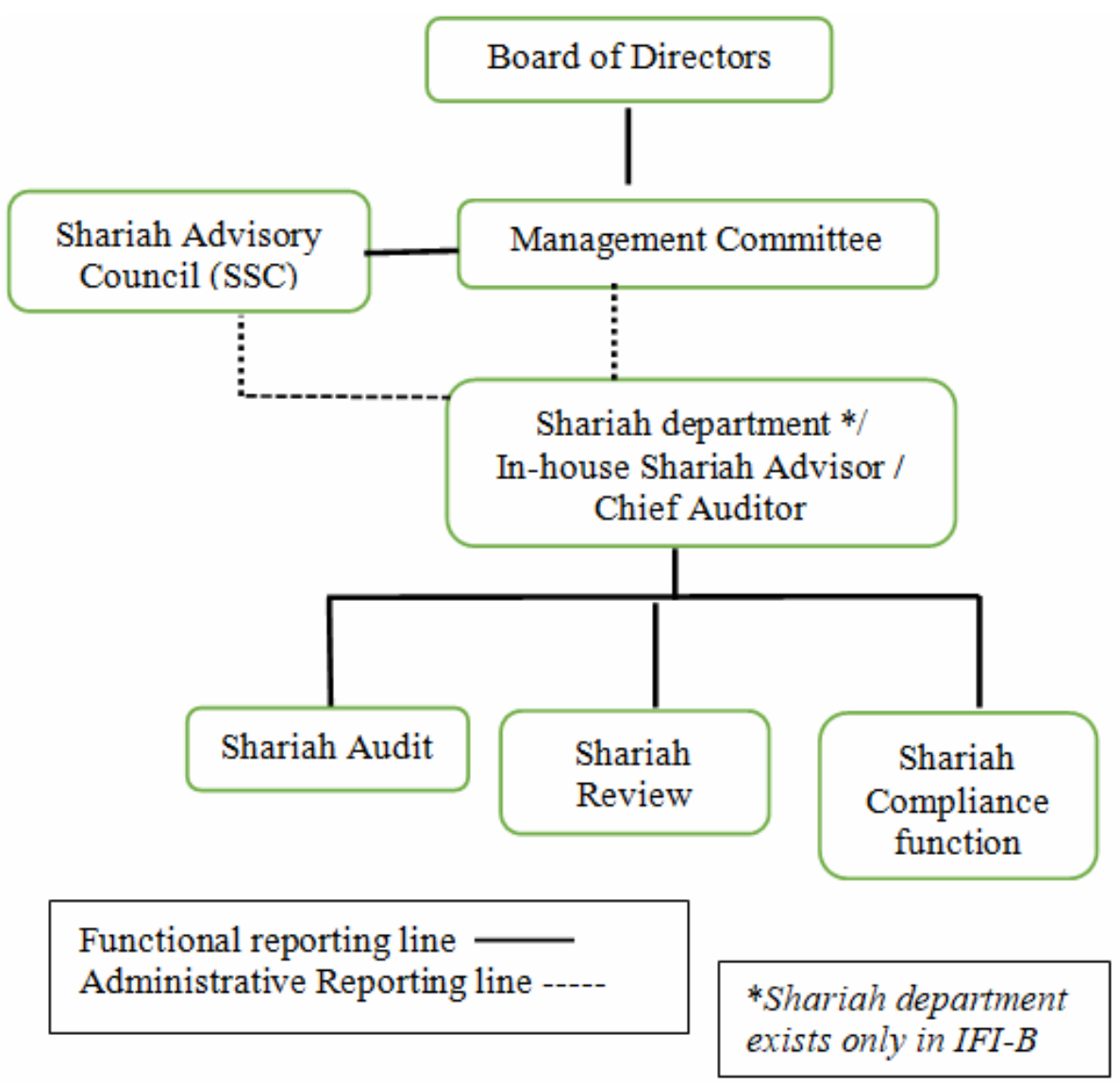

Source: Authors' Own

Figure 2 illustrates the Shariah review and Shariah audit functions are carried out by IFIs but the structure and the reporting lines are different from IFI-A's structure as it is illustrated in Figure 1.

Based on the above analysis and discussion, it has been found that, the IFIs in Sri Lanka follow AAOIFI and IFSB to ensure Shariah governance in their practices though the country's regulation is silent in this regard. All of the IFIs in Sri Lanka follow AAOIFI Standards except for IFI-A, which follows both AAOIFI and IFSB Standards. However, in terms of Shariah governance framework, IFI-A follows IFSB10. All of them have the structure and process that supports Shariah governance. However, there are some different aspects of practices that are identified as compare to the guidelines or the standard that they follow. These different approaches however are not significant and thus considered as minor gaps. The following table illustrates the findings on the gaps: 
Table 3: Summary of Findings

\begin{tabular}{ccccc}
\hline $\begin{array}{c}\text { Islamic } \\
\text { Financial } \\
\text { Institutions }\end{array}$ & $\begin{array}{c}\text { Internal } \\
\text { arrangements }\end{array}$ & $\begin{array}{c}\text { Shariah } \\
\text { Board }\end{array}$ & $\begin{array}{c}\text { Internal } \\
\text { Shariah audit }\end{array}$ & $\begin{array}{c}\text { Shariah } \\
\text { review }\end{array}$ \\
\hline A & $\checkmark$ & $\checkmark$ & $\checkmark$ & $\checkmark$ \\
B & $\checkmark$ & $\checkmark$ & $\checkmark$ & $\checkmark$ \\
C & $\sqrt{ }$ (Minor gap) & $\checkmark$ & $\checkmark$ & $\checkmark$ \\
D & $\sqrt{ }$ (Minor gap) & $\checkmark$ & $\checkmark$ & $\checkmark$ \\
E & $\sqrt{ }$ (Minor gap) & $\checkmark$ & $\checkmark$ & $\checkmark$ \\
F & $\sqrt{ }$ (Minor gap) & $\checkmark$ & $\checkmark$ & $\checkmark$ \\
\hline
\end{tabular}

\section{Recommendation and Conclusion}

The findings of this study show that the Shariah governance structure and process are in place in all IFIs in Sri Lanka. However, due to a number of issues such as lack of qualified human capital and other unique challenges faced by the respective IFIs, they have adopted different structure and process as required by the regulations that they are supposed to follow. Such a situation may expose the IFIs to the legal and regulatory risks. The regulator may temporarily compromise such non-compliance due to prevalent issues faced by the IFIs and the industry, but it should not be a permanent exception.

To rectify the gaps in the practice, few recommendations may be considered. The setting up of a central SSB as an independent common body of scholars by the collective effort of IFIs shall be beneficial for the entire industry, not only to harmonise the Shariah governance practices but also other aspects such as product offerings and services to the public. This body may issue guidelines considering domestic market or otherwise it may recommend that all IFIs shall follow recognised international Shariah standards, with modification to suit the local condition and existing legislations. This body may provide solutions to the issues of practice-gap by issuing guidelines on Shariah governance process and structure including internal and external setup, how Shariah review and Shariah audit should be carried out, Shariah review and audit report, and the like. As part of good disclosure practice, it is recommended that this body publish the annual report to the stakeholders and public at large.

All Ceylon Jamiyathul Ulama (ACJU) is the apex body of Islamic theologians in Sri Lanka incorporated under the Act of Parliament No. 51 of 2000. It is not a government authorised body but is well-known and widely recognized body among the Muslims in Sri Lanka since pre-independence time of 1924. ACJU played a significant role in providing Shariah supervisory services to IFIs between 2010 and 2013, but later on ACJU discharged itself from doing so. However, its members continue to serve as SSB members in their individual capacity. This body can be reconsidered in the context of establishing a common central body for Shariah governance at the micro level. Indeed, some of the interviewee agreed to the proposal of having ACJU as the Central SSB as

International Journal of Management and Applied Research, 2019, Vol. 6, No. 4 
this may bring many advantages to the industry where currently there is no specific legislation on Shariah governance.

Among the roles that ACJU can play is that the issuance of guidelines to standardise the Shariah governance process and structure. This is not new to ACJU since it had already issued a few guidelines based on AAOIFI Standards and country regulations with the support of IFIs in 2007. The guidelines consist of ten chapters including introduction, form and structure of the IFI, staff, operating procedures, documents and agreements, treasury operations, and business prohibitions. Having a legally recognised and reputable body as the Central SSB shall increase IFIs' creditability and public confidence. Thus this will be beneficial to all IFIs as they will have good reputation and at the same time it shall pave the way to further develop the market.

This study strongly recommends all IFIs in Sri Lanka to establish internal policies or by-laws on Shariah governance which comprises entire structure, process and other aspects of Shariah governance. This seems appropriate in the Sri Lankan context whereby each IFI adopt dissimilar practices on Shariah governance though most of them follow AAOIFI Standards. Each IFI should prepare specific internal policies that describe the entire elements of Shariah governance that the IFI is going to follow based on its business and specific circumstances. This may include the structure, process, SSB members, appointment, qualification, and publication of SSB's product approval and audit reports. Further, the policies shall be disclosed to the public for their reference so that the public can go through the policies and decide whether the company has exercise good Shariah governance practices or otherwise. Further, the public can easily determine whether the IFIs' practices comply with the policies disclosed. Such a disclosure positively permeates confidence of the public and other stakeholders to the IFIs and the industry as a whole.

\section{References}

1. Accounting, Auditing and Governance Standards for Islamic Financial Institutions (AAOIFI) (2015), Governance Standard, Bahrain: AAOIFI.

2. Amana Bank (2019), Board of Directors, [Online] available from: https://www.amanabank.lk/about-us/board-of-directors.html\# [Accessed on 4 July 2019].

3. Bank Negara Malaysia (BNM) (2011), Guidelines on Shariah Governance Framework for Islamic Financial Institutions. Kuala Lumpur: Bank Negara Malaysia.

4. Buallay, A. (2019), "Corporate governance, Shariaah governance and performance", International Journal of Islamic and Middle Eastern Finance and Management, Vol. 12 No. 2, pp. 216-235. https://doi.org/10.1108/IMEFM-072017-0172.

International Journal of Management and Applied Research, 2019, Vol. 6, No. 4 
5. Daily FT (2015), Ceylinco Islamic Bank depositors submit petition to Maithri, [Online] available from: http://www.ft.lk/financial-services/ceylinco-islamic-bankdepositors-submit-petition-to-maithri/42-385977 [Accessed on 3 July 2019].

6. Ginena, K., and Hamid, A. (2015), Foundations of Shariah Governance of Islamic Banks, United Kingdom: John Wiley \& Sons Ltd.

7. Hakim, A. L. (2017), "Application of Three Lines of Defence in Islamic Financial Institution", International Journal of Management and Applied Research, Vol. 4, No. 1, pp. 44-57. https://doi.org/10.18646/2056.41.17-005

8. Haqqi, A. R. A. (2014), "Shariah Governance in Islamic Financial Institution: An Appraisal", Us-China Law Review, Vol. 11, No. 112, pp. 112-133.

9. Hasan, Z. (2010), "Regulatory Framework of Shariah Governance System in Malaysia, GCC Countries and the UK", Kyoto Bulletin of Islamic Area Studies, Vol. 3, No. 2, pp. 82-115.

10. Hasan, Z. (2011), “A survey on Shari'ah governance practices in Malaysia, GCC countries and the UK", International Journal of Islamic and Middle Eastern Finance and Management, Vol. 4, No. 1, pp. 30-51. https://doi.org/10.1108/17538391111122195

11. Islamic Financial Service Board (IFSB) (2009), Guiding Principles on Shari'ah Governance Systems for Institutions Offering Islamic Financial Services. Kuala Lumpur: IFSB.

12. Kuwait Finance House Research Ltd (2013), Islamic Finance in Asia: Development, Growth and Opportunities. Kuala Lumpur: Kuwait Finance House.

13. Mizushima, T. (2013), "Corporate Governance and Shariah Governance at Islamic Financial Institutions: Assessing from Current Practice in Malaysia", Reitaku Journal of Interdisciplinary Studies, Vol. 22, No. 1, pp. 59-84.

14. Muhammad (1414) Lisan al Arab. Beruth: Dar Sadir.

15. Oxford Dictionaries (2013). English Oxford Living Dictionaries.

16. Patel, G. (2017), "Islam and capital, mortared by trust: the case of Sri Lanka", Society and Business Review, Vol. 12 No. 3, pp. 373-394. https://doi.org/10.1108/SBR-07-2017-0045

17. Shafii, Z.; Supiah, S. and Syahidawati, S. (2010), "Management of Shariah NonCompliance Audit Risk in the Islamic Financial Institutions via the Development of Shariah Compliance Audit Framework and Shariah Audit Programme", Kyoto Bulletin Of Islamic Area Studies, Vol. 3, No. 2, pp. 3-16.

International Journal of Management and Applied Research, 2019, Vol. 6, No. 4 